A3

doi: $10.14232 /$ fgykf.2018.a3

\title{
Egyszerű gél-előhívási módszer mirozináz enzimaktivitás detektálásához
}

\author{
Plaszkó Tamás, ${ }^{1}$ Szúcs Zsolt, ${ }^{1}$ Cziáky Zoltán, ${ }^{2}$ Kiss-Szikszai Attila, ${ }^{3}$ \\ Vasas Gábor, ${ }^{1}$ M-Hamvas Márta, ${ }^{1}$ Gonda Sándor ${ }^{1}$ \\ ${ }^{1}$ Debreceni Egyetem, Növénytani Tanszék, 4010 Debrecen, Egyetem tér 1 \\ ${ }^{2}$ Nyíregyházi Egyetem, Agrár és Molekuláris Kutató és Szolgáltató Int., 4400 Nyíregyháza, Sóstói út 31/b \\ ${ }^{3}$ Debreceni Egyetem, Szerves Kémiai Tanszék, Debrecen 4010, Egyetem tér 1
}

A mirozináz a Brassicaceae család számos tagjában előforduló enzim. Glükozinolát vegyületeket hidrolizál, melyek azután különféle illékony, bioaktív vegyületekké rendeződnek át pl.: nitrilek, tiocianátok, izotiocianátok. Az izotiocianátok jól ismertek antimikrobiális és antikarcinogén tulajdonságaik miatt és ezen vegyületeknek köszönhetjük számos növény emberre gyakorolt jótékony hatását pl: Armoracia rusticana (torma).

Kutatásunk során azt a célt tûztük ki magunk elé, hogy egy olyan egyszerű és reverzibilis módszert fejlesszünk ki, melynek segítségével detektálhatjuk a mirozináz aktivitást PAGE és SDS-PAGE módszerekkel elválasztott fehérjekivonatoknál. Az előhívó reagens elkészítéséhez metilvörös festéket használtunk, amely intenzív vörös sávokat produkált glükozinolátok enzimatikus hidrolízise során felszabaduló $\mathrm{HSO}_{4}^{-}$ ionok jelenlétében. Ezután az aktivitást mutató gélsávokat kivágtuk és származékképző oldatban inkubáltuk annak érdekében, hogy bebizonyítsuk hogy az általunk detektált reakció valóban mirozináz volt. LC-ESI-MS méréssel ezt sikerült is bizonyítani az inkubáló oldatokban mirozináz enzim által létrehozott allil-izotiocianát volt detektálható.

A módszert sikeresen alkalmaztuk elsősorban torma gyökerekből, illetve egyéb Brassicaceae növények különböző részeiből (pl.: mustár, kelbimbó, brokkoli) készített enzimkivonatokon. Ezenfelül tormából izolált endofiton gombák enzimkivonataiban is sikerült mirozináz-szerű enzimaktivitást kimutatni. A módszerünk gyorsnak, egyszerúnek és hatékonynak mutatkozott, amellyel detektálhatunk és részlegesen karakterizálhatunk glükozinolát bontó enzimeket különféle nehezen kivitelezhető fehérjetisztítási eljárások nélkül. 